\title{
THE USE OF ORAI MOBILE APPLICATION TO TEACH SPEAKING IN EFL CLASSES
}

\author{
Ni Kadek Sutami \\ English Language Education Study Program \\ Ganesha University of Education \\ sutamimade11@gmail.com)
}

\begin{abstract}
This paper is aimed to describe how to implement ORAI mobile application to teach speaking in EFL classes. As library research, the data were collected by analyzing articles, journals, and papers. This paper used the descriptive qualitative method. The finding of this paper showed that the use of ORAI mobile application is effective for learning speaking skills. The students feel fun and confidence in speaking after learning through ORAI. However, it is famous as an application to improve speaking skills, and it eventually can be used for other skills. The teacher will be helped to maximize the students in practicing to speak in English. ORAI mobile application can be used to control the students' progress in speaking, especially in pronunciation. This paper discusses the modified version of the ORAI mobile application and then argues the expected impacts.

Keywords: ORAI mobile application, Speaking skill, EFL classes
\end{abstract}

\section{Introduction}

English is categorized as an international language that is used by many countries in the world. Further, English as a foreign language in Indonesia makes using English is challenging. However, learning is essential as it is an open global era; English communication is avoidable (Noprival, 2016). Suppose students can speak English in a good way. In that case, it will help the student's future, as now the development of tourism objects in Indonesia, the emerging technology in which students use or speak English is needed. Many different aspects appear in English which do not appear in the Indonesian language. However, the four basic skills remain the same; four basic skills in English are listening, speaking, reading, and writing. Those four skills are essential and need to be developed when the students want to master English well. Thus, a teacher's role in teaching English needs to be more concerned about how to teach the skills in one activity in the classroom.

Integrating English skills in the classroom is needed. Students can learn more if they are involved in the teaching and learning process. Integrated skills involve more than one skill in the teaching and learning process (Tajzad \& Namaghi, 2014). Students cannot use the language well if they learn the skill separately. This kind of strategy can have a positive impact on the students. Pardede (2017) stated that by integrating the four skills, the students could develop their communicative competence and use English. It is said that it can develop communicative competence because by integrating the four skills, the students will be able to use all senses, which will optimize them to absorb the information. Other than that, when they do all skills, they will be more active in the class. They will produce the language and get the information. Thus the students will quickly produce the language and be able to speak the language.

A Smartphone might be a medium to teach the four essential skills especially speaking skills. It allows students to learn English inside or outside the classroom, but it is still limited to use by students (Ahn \& Lee 2016). Mobile-assisted language learning (MALL) deals with using mobile technology in language learning. Usually, students learn a second language in the classroom, while through MALL, students do not always study a second language in a classroom. They will have the opportunity to learn it using mobile devices when they want to (Miangah, 2012). This means that nowadays, students are free to learn any time and everywhere. Through advanced 
technologies, mobile-assisted language learning gives a revolution in the teaching and learning process (Mohammadi \& Safdari, 2015). Nowadays generation, students are familiar with a smartphone. Zou, Li, and Hui, (2018) argued that the current generation could be considered the "Mobile Generation" because they mostly used mobile devices than any other generation.

The teacher needs to look at this issue in the learning process because some teachers still only stick to one media, for instance, LKS or coursebook (Rahmah, Jamilah, \& Siti, 2014). Smartphone facilitates many applications which can help students in learning a language. Guo (2014) stated that mobile applications are underpinned mainly by behaviorist theory since most consider the drill and practice activity. One of them is ORAI mobile application. It offers many features for students to practice speaking English. In addition, the main one of this application is that it provides the feedback given in which it will tell the students about the quality of their speaking. Additionally, it can also be used to integrate the four skills because features can be used to maximize listening, writing, and reading skill, depending on how to develop the media and use it appropriately.

Halimah, Lustyantie, and Ibrahim (2018) stated that ORAI is an application to help people be better speakers, which Danish Dhamani develops. This application is simply a mirror to the user because it will give the user feedback. It provides the speaker with their ability in speaking, especially in speech. This app picks up on filler words, telling the speaker or user if they speak too fast or too slow, varying their energy, and monitoring the pace of their speech. These things can give a reflection to the speaker directly. In addition, in ORAI new version, some lessons can be done by the speaker. At this level, the speaker will be able to speak spontaneously or plan.

This application targets high school students, college students, and young professionals (Halimah et al., 2018). Halimah et al. (2018) had researched students' perceptions in using ORAI in the CLL method. The sample of the research were first semester students of University in East Java- Indonesia, and the result of the research stated the used of ORAI in CLL method can minimize students' anxiety in speaking. Similarly, Putra, Susanti, and Santosa (2018) also found that the freshman students taught using ORAI mobile application had better performance and significantly affected speaking competency than the students in conventional learning.

Those researches show that ORAI mobile application is giving a positive effect on students speaking competency. It is expected to support students in learning English. Both of the researchers above use the application for speaking.

\section{Research Methodology}

This paper is library research; library research is gaining the data by reading the literature from printed textbooks, articles or periodical journals, and other related resources (Efriana, 2021). The data were analyzed qualitatively. Thus the method of this study is the descriptive qualitative method. Miles and Huberman (1994) state that the data is described in four-step steps: data collection, data reduction, data display, and conclusion. Thus in this paper, the data gained through analyzing papers, journals, and articles.

\section{Finding and Discussion}

Some researches had already been done before that related to the use of mobile devices in learning speaking skills. Ahn \& Lee (2016) discussed the students' attitude towards learning speaking as EFL in Korea by using mobile applications in terms of Automatic Speech Recognition (ASR) it is Speaking English 60 Junior. The researcher used open-ended questionnaires to gain the data. The result showed that the students with positive attitudes towards this strategy showed they are interested in learning to speak by using ASR. Even though this study did not focus on achievement, but from students' positive responses, it can be concluded that they enjoy and like to use ASR in learning to speak English. Different from that, Howlett \& Zainee (2019) had done the research in Thai about the students' perception in using mobile devices to learn English as EFL. It used quantitative design and questionnaires used to get the data. The result showed that the students agree/strongly agree that mobile devices give 
them a positive impact and help them to learn English. Students' attitudes and perceptions already showed a good result in using mobile devices.

In addition, Putra et al. (2018) also had researched the effect of using ORAI Smartphone-based application on adult learners' speaking skills. The research was done in English Language Education Department in North Bali, Indonesia. The research population is 215 freshman students, with the sample chosen two classes by using random cluster sampling. This research is experimental research that used SPSS to analyze the data. The result of this data showed that ORAI Smartphone-based application has a positive effect on students speaking skills. It can be seen from the different results of students who were taught by using conventional learning, which had a lower score than the students who were taught by giving treatment in using ORAI mobile application.

Those researches prove that using mobile devices and ORAI has a positive impact on the students. It allows learning something new which uses technology. ORAI mobile application is usually used for speaking. However, some features can be emphasized in writing because they need to make the text first before they speak. In addition, it depends on how the technique is used and created by the teacher. In this implementation, ORAI will be used to integrate the four skills.

\section{Implementation}

The implementation of using ORAI mobile application to teach speaking in EFL classes is as follows:

First, the teacher asks the students to download ORAI mobile application by visiting the Google play store. The teacher will ask the students to a short descriptive text. After the students write their text, they will be asked to record it in the ORAI mobile application. They will be asked to record it until they think the recording is better than the other, and the ORAI application's comment also proves that they have already tried until getting better. In this case, they have already learned speaking skills.

Lastly, the students will be asked to revise their works and record again in ORAI several times because the result of $O R A I$ analysis will be submitted to the teacher.

, the implementation of the use of ORAI in EFL classes can be seen in this figure.

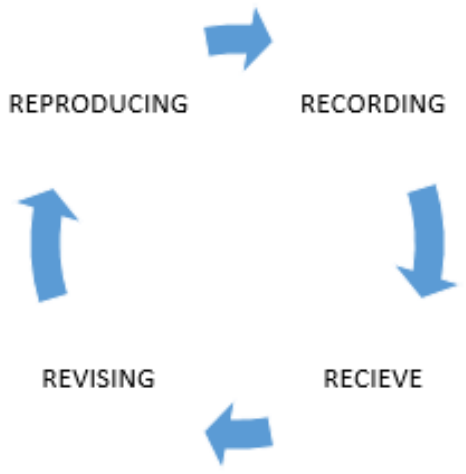

Figure 1. Learning cycle using ORAI application by Suryani et al. (2019)

Suryani et al. (2019) state that there is four procedure to learn speaking English using ORAI especially in learning pronunciation.

The first is recording; the students will be asked to record their speaking by reading the text given in ORAI. There is much text in this application that the students can use to practice speaking in English. The students did not have to worry about the topic for the speaking exercise. In addition, there are also some questions and answers provided by ORAI. Thus the students can learn to speak directly and spontaneously.

The second is receiving; the applications will show the students how accurate their pronunciation and pace are in percentages after recording. The students can also see their progress in speaking by looking for the graph provided by the application. It can help the 
students and teacher know the students' progress, and the teacher can also make sure that the students do the exercise.

The third is revising; after receiving, the students will know their self-assessment about their ability in speaking, especially in pronunciation. ORAI will give feedback based on students' recording; if the students read the text which is not similar to the actual text given or talk out of the topic, the applications will ask the students to record or revise it. Furthermore, if the students have low results, they can revise and re-record it with the instruction by the teacher.

The fourth is reproducing; after revising the talk, the students can reproduce it until they get the target score and give it to the teacher.

Using ORAI in learning speaking for the students will make them feel confident about speaking; it is because the students feel that they have been practiced and will gain more used to speaking. According to Saripudin et al. (2020), the students felt learning with this application was compelling and fun. The students are happy to learn through ORAI.

\section{The Impacts of Implementing Orai Mobile Application in EFL Classes}

Technology develops rapidly in this era because it can give people many benefits in daily life. However, as it is a media, there will not be perfect. Some weaknesses might be appeared in implementing this mobile application. However, the below also shows how to overcome the weakness. There might be noise in class because they will record their voice in the class. It does not matter in recording, the teacher can ask the students to record it freely in class, not only sitting but they can go to the corner to record it. In addition, when they record it, they can close their mouths to the phone, so the other sound will not be disturbing.

There are also expected impacts as a result of implementing this application. The students are expected to improve the four skills especially speaking skills, because they will record them until they feel satisfied. Moreover, it is supported by the correction of the ORAI mobile application. The students are trained to speak repeatedly in $O R A I$ until the feedback is more positive. The students are expected to learn collaboratively as it is done in the group. This media is used in a group of students and do some assignments together. Thus they will be able to work collaboratively. The students are expected to be more detailed in writing and speaking skills because, in the implementation, they are asked to analyze the text as well. The students are expected to think creatively because making the text without stating the place's name is problematic.

\section{Conclusion}

Based on the explanation above, speaking skill is needed by the students. It is because speaking skills can develop students' communicative skills. Communicative skill means the ability to use the language in doing communication. As in daily life, students use all of the skills when doing interaction and speaking skill is the skill which can convey the idea. However, the use of technology is also appropriate. The characteristics of nowadays generation are they tend to use technology in daily life becomes they used to use it. Giving them mobile applications will be easy to be accepted and make the learning process enjoyable. ORAI mobile application is one of those media; this application is famous for supporting speaking skills. However, if it is implemented with the proper technique, it can also be used to teach English in integrating the four languages skills.

\section{References}

Abdulah, A. Q. (2013). Not Just Wanna Have Fun: Teaching Listening Skills with Songs, 4(2), 2-4.https://doi.org/10.7575/aiac.alls.v.4n.2p.96

Ahn, T., \& Lee, S. (2016). automatic speech recognition for EFL learning, (2015). https://doi.org/10.1111/bjet.12354

Ariyanti, A. (2016). The Teaching of EFL Writing in Indonesia. Dinamika Ilmu, 16(2), 263. https://doi.org/10.21093/di.v16i2.274 
Africa, 1. (2021). Problems of online learning during covid-19 pandemic in EFL classroom and the solution, 2(1), 38-47.

Guo, H. (2014). Analysing and evaluating current mobile applications for learning English speaking. British Council ELT Master's Dissertation Awards: Commendation, 2-92. Retrieved

from https://englishagenda.britishcouncil.org/sites/default/files/filefield_paths/analysing_and_ evaluating_current_mobile_applications_v2.pdf

Halimah, H., Lustyantie, N., \& Ibrahim, G. A. (2018). Students' Perception on the Implementation of ORAI mobile application in Call Method in Teaching Speaking. JEELS (Journal of English Education and Linguistics Studies), 5(1), 1-22. https://doi.org/10.30762/jeels.v5i1.566

Harmer, J. (2002). The Practice of English Language Teaching. New York: Longman.

Howlett, G., \& Zainee, W. (2019). 21st Century Learning Skill and Autonomy: Students' Perceptions of Mobile Devices in the Thai EFL Context. Teaching English with Technology, 19(1), 72-85.

Jalilifar, A. (2010). The effect of cooperative learning techniques on college students ' reading comprehension. System, 38(1), 96-108. https://doi.org/10.1016/j.system.2009.12.009

Kirbas, A. (2017). International Journal of Languages 'Education and Teaching, 5(1), 1-17.

Miles, M.B. \& Huberman, A. . (1994). Matthew B. Miles, A. Michael Huberman - Qualitative Data Analysis_ An Expanded Sourcebook-Sage Publications, Inc (1994) (1).pdf.

Mohammadi, M., \& Safdari, N. (2015). Pedagogical values of mobile-assisted task-based activities to enhance speaking skill, (2015), 416-420. https://doi.org/10.14705/rpnet.2015.000368

Nunan. (1999). Developing Assessment For Speaking Yenny Rahmawati \& Ertin.

Pardede, P., \& Indonesia, U. K. (2019). Proceeding efl theory \& practice: voice of eed uki, (February 2017).

Polat, M. \& Erişti, B. (2019). The effects of authentic video materials on foreign language listening skill development and listening anxiety at different levels of English proficiency. International Journal of Contemporary Educational Research, 6(1), 135-154. DOI: https://doi.org/10.33200/ijcer.567863

Rahmatunisa, W. (2014). Problems faced by Indonesian EFL learners. journal of English education, 3(1).

Santosa, M. H. (2019). Investigation of the Effect of ORAI Smartphone-Based Application on Speaking Competency for Adult Learners, (October 2018).

Sayuri. (2016). English Speaking Problems of EFL Learners of Mulawarman University. Indonesian Journal of EFL and Linguistics, 1(1), 47-61

Sharafi Nejad, M., Raftari, S., Ismail, S. A. M. M., \& Eng, L. S. (2016). Iranian EFL Learners' Writing Problems: A Move towards Solution. Journal of Studies in Education, 6(4), 110. https://doi.org/10.5296/jse.v6i4.10203

Suryani, L., Syahrizal, T., \& Fauziah, U. N. E. (2019). Using ORAI application in teaching pronunciation. Indonesian EFL Journal, 5(2), 93-102. doi: 10.25134/ieflj.v5i2.1835.

Saprudin, T., Kurniawati, N., and Maolida, E. H., (2020). The implementation of orai application in teaching, $8(01)$.

Zou, B., Li, H., \& Li, J. (2018). Exploring a curriculum app and a social communication app for EFL learning. Computer Assisted Language Learning, 31(7), 694-713. https://doi.org/10.1080/09588221.2018.1438474 